JBEE: JOURNAL BUSINESS, ECONOMIC AND ENTREPRENEURSHIP

https://journal.shantibhuana.ac.id/index.php/bee/index

JBEE Volume 3 No 12021

\title{
ANALISIS KINERJA KEUANGAN PT BANK UOB INDONESIA, TbK DENGAN METODE CAMEL (CAPITAL, ASSET, MANAGEMENT, EARNING, LIQUIDITY) \\ PERIODE 2016 s.d 2018
}

\author{
Sri Novita \\ Akademi Keuangan Dan Perbankan Grha Arta Katulistiwa \\ srinovita0987@gmail.com
}

Received: 17 Maret 2021; Accepted: 18 Maret 2021; Published: 30 April 2021

\begin{abstract}
Abstrak
Metode CAMEL merupakan alat analisis yang bertujuan untuk menilai dan mengukur tingkat kesehatan perusahaan perbankan berdasarkan rasio-rasio keuangan yang ditekankan pada lima aspek yaitu modal, kualitas, aktiva, manajemen, pendapatan dan likuiditas. Yang menjadi objek dalam penelitian ini adalah PT Bank UOB Indonesia, Tbk periode 2016 s.d 2018. Tujuan dalam penelitian ini adalah untuk menganalisa kinerja keuangan PT Bank UOB Indonesia, Tbk. Metode yang digunakan dalam penelitian adalah metode deskriftif.

Hasil penelitian menunjukkan nilai bersih aspek (CAMEL) pada tahun 2016 sebesar 95,55 poin, pada tahun 2017 sebesar 98,35 poin dan pada tahun 2018 sebesar 96,9 poin. Artinya tingkat kesehatan PT Bank UOB Indonesia Tbk sesuai dengan standar yang telah ditetapkan oleh Bank Indonesia dan dikategorikan Sehat.
\end{abstract}

Kata kunci: Modal, Kualitas, Aktiva, Manajemen, Pendapatan Dan Likuiditas.

\section{PENDAHULUAN}

\section{Latar Belakang}

Sektor perbankan merupakan sektor yang sangat maju, yang kemajuannya diiringi dengan berbagai kecanggihan teknologi dan semakin meningkatnya kesadaran pendidikan dan ilmu pengetahuan. Tingkat kesehatan bank dapat dinilai dalam beberapa faktor, salah satu faktor yang digunakan adalah laporan keuangan bank yang bersangkutan. Berdasarkan laporan keuangan, dapat dihitung sejumlah rasio keuangan yang bisa dijadikan dasar penilaian tingkat kesehatan bank.
Bank merupakan lembaga keuangan yang menjadi tempat bagi perusahaan, badanbadan pemerintah dan swasta, ataupun orang-orang yang menyimpan dana, bank juga merupakan suatu lembaga yang berperan sebagai perantara keuangan antara pihak-pihak yang memiliki dana maupun pihak- pihak yang memerlukan dana.

Lembaga perbankan kerap dijuluki sebagai lembaga keuangan yang memiliki sifat "khusus" hal itu terlihat dari sudut pandang mikro dan makro. Dari sudut pandang mikro, penyaluran jasa kredit yang di berikan oleh lembaga perbankan 
43 | Sri Novita. Analisis Kinerja Keuangan Pt Bank Uob Indonesia, Tbk Dengan Metode Camel (Capital, Asset, Management, Earning, Liquidity) Periode 2016 S.D 2018

mampu menstimulus roda perekonomian suatu negara. Dari sudut pandang makro, lembaga perbankan menjadi lembaga yang menetapkan kebijakan moneter. Untuk itu Lembaga perbankan dalam menjalankan fungsinya wajib melaksanakan pengelolaan yang prudent dan wajib menjaga kepercayaan nasabahnya. Kepercayaan nasabah merupakan hal yang sangat penting agar kegiatan operasional perbankan dapat berjalan dengan baik. Hal itu juga harus di dukung oleh tindakan pengawasan (supervising) yang di lakukan oleh lembaga pengawas perbankan yaitu Bank Indonesia agar lembaga perbankan Indonesia tidak rentan terhadap berbagai guncangan ekonomi baik yang berasal dari dalam negeri maupun luar negeri. Demi menjaga kepercayaan para deposan dan stabilitas sistem pembayaran, bank-bank yang beroperasi perlu di nilai tingkat kesehatannya. Tata cara peniliaian kesehatan bank diatur dalam SK Direksi BI No.31/11/KEP/DIR tanggal 30 April 1997 dan telah di ubah dengan SK Direksi BI tanggal 30 Mei 2004.

Peraturan bank Indonesia Nomor 6/10/PBI/2004 tanggal 12 April 2004 tentang Sistem Penilaian Tingkat Kesehatan Bank IUmum (Lembaran Negara Republik Indonesia Tahun 2004 Nomor 38, Tambahan Lembaran Negara Nomor 4382) Bank Wajib melakukan penilaian Tingkat Kesehatan Bank secara Triwulan dan mulai tahun 2012 penilaian sendiri (self assessment) dilakukan paling kurang setiap semester untuk posisi akhir Juni dan Desember apabila terdapat perbedaan penilaian hasil yang di lakukan oleh Bank itu sendiri dengan Bank Indonesia, maka yang berlaku adalah penilaian menurut Bank Indonesia. Tingkat kesehatan bank dapat dinilai dari beberapa indikator. Salah satu sumber utama yang dapat di jadikan bahan di perlukan pengawasan dan pengaturan yang khusus pula bagi lembaga perbankan untuk menjaga kestabilitasan perekonomian negara kita.

penilaian adalah melalui laporan keuangan yang di terbitkan oleh bank yang bersangkutan.

Melalui laporan keuangan yang di terbitkan dapat di hitung sejumlah rasio keuangan yang lazim dijadikan dasar penilaian tingkat kesehatan bank. Penilaian ini dapat dilakukan dengan melihat sisi kinerja laporan keuangan. Kinerja melihat pada neraca laporan laba rugi dan laporan arus kas serta hal-hal lain yang turut mendukung sebagai penguat penilaian kinerja keuangan tersebut. Menurut Kasmir (2016: 10), "Secara umum laporan keuangan bertujuan untuk memberi kan informasi keuangan suatu perusahaan, baik pada saat tertentu maupun pada periode tertentu."

Agar pihak-pihak yang bersangkutan dapat memperoleh informasi keuangan yang memadai dan akurat, maka perlu diadakan interprestasi terhadap laporan keuangan. Dalam menganalisis dan menginterprestasikan laporan keuangan yang bersangkutan, maka penilaian untuk mengetahui kondisi suatu bank, biasanya menggunakan berbagai alat ukur, salah satunya alat ukur yang diginakan untuk menentukan kondisi suatu bank dikenal dengan nama analisis CAMEL.

Analis rasio keuangan yang di gunakan dalam penilaian tingkat kesehatan bank adalah dengan menggunakan rasio CAMEL yaitu: 1) capital; 2) assets; 3) management; 4) earnings; 5) liquidity. Aspek - aspek tersebut menggunakan rasio keuangan yang di sajikan melalui laporan keuangan perusahaan yang di terbitkan setiap tahunnya.

Tujuan dari analisis menggunakan rasio CAMEL untuk menentukan tingkat 
kesehatan bank adalah untuk mengetahui kondisi bank tersebut yang sesungguhnya apakah dalam keadaan sehat, kurang sehat atau mungkin tidak sehat. Dalam menghadapi persaingan dibidang perbankan yang semakin ketat, kepercayaan dari masyarakat merupakan salah satu kunci sukses yang mendorong kemajuan perusahaan. Agar lebih dipercaya oleh pemerintah dan masyarakat dalam pengelolaan keuangan bisnisnya, maka kepentingan akan pengukuran tingkat kesehatan bank sangat perlu dilakukan oleh perbankan BUMD dan juga perbankan BUMN.

Dalam penelitian ini peneliti menggunakan rasio CAMEL yaitu: 1) capital; 2) assets; 3) management; 4) earnings; 5) liquidity. Hasil dari masingmasing asek ini kemudian menghasilkan kondisi keuangan suatu bank tersebut. Dalam penelitian ini peneliti menganalisis tingkat kesehatan bank untuk menilai kinerja keuangan bank. Dengan melihat laporan neraca dan laporan laba rugi, dimana laporan neraca terdiri dari aktiva, kewajiban dan ekuitas, sedangkan laporan laba rugi merupakan laporan tentang pendapatan bersih atau kerangka operasional. Sehingga dengan analisis CAMEL bisa mengetahui kinerja dibidang keuangan tersebut. Hasil analisis tersebut sangat penting, artinya bagi pemimpin bank untuk mengontrol kebijakankebijakan yang telah diambil baik kondisi keuangan yang lalu, saat ini maupun yang akan datang dalam menjalankan operasional bank dan membantu dalam mengambil keputusan yang harus dilakukan secepat mungkin tentunya agar tujuan bank dapat tercapai dengan baik.

\section{Kajian Teori \\ Pengertian Kinerja Keuangan}

Kinerja keuangan adalah suatu gambaran tentang kondisi keuangan suatu bank yang dianalisis dengan alat-alat pengukur keuangan sehingga dapat diketahui mengenai kondisi baik batau buruknya keadaan suatu bank yang mencerminkan prestasi kinerja bank tersebut dan dapat diukur karena hasilnya dapat dipakai sebagai dasar pengambilan keputusan baik bagi pihak internal maupun pihak eksternal.

Kinerja keuangan juga diartikan sebagai gambaran pencapaian perusahaan berupa hasil yang telah dicapai melalui berbagai aktivitas untuk meninjau sejauh mana suatu bank telah melaksanakan standar akuntansi keuangan dengan baik dan benar yang mencakup tujuan dan contoh analisis laporan keuangan.

Menurut Harmono (2011: 32), "Kinerja perusahaan umumnya diukur berdasarkan penghasilan bersih (laba) atau sebagai dasar bagi ukuran yang lain seperti imbalan investasi (return on ivestion) atau pengahasilan persaham (earnins per shere) unsur yang berkaitan langsung dengan pengukuran bersih (laba) adalah penghasilan ddan beban".

Untuk dapat memperoleh gambaran tentang perkembangkan keuangan suatu bank perlu diadakan interprestasi atau analisis terhadap data keuangan dan data keuangan tersebut tercermin didalam laporan keuangan bank yang akan diteliti.

\section{Pengertian Bank}

Sejarah dikenalnya asal mula kegiatan perbankan dimulai dari jasa penukaran uang. Oleh karena itu bank dikenal sebagai tempat menukar uang atau sebagai meja tempat menukarkan uang. Dalam sejarah para pedagang dari berbagai kerajaan melakukan transaksi dengan menukarkan uang, di mana penukaran uang dilakukan antar mata uang 
45 | Sri Novita. Analisis Kinerja Keuangan Pt Bank Uob Indonesia, Tbk Dengan Metode Camel (Capital, Asset, Management, Earning, Liquidity) Periode 2016 S.D 2018

kerajaan yang satu dengan mata uang kerajaan yang lain. Kegiatan penukaran uang ini sekarang dikenal dengan perdagangan valuta asing (money changer).

Mendengar kata bank sebenarnya tidak asing lagi bagi kita, terutama yang hidup di perkotaan. Bahkan di pedesaan sekalipun saat ini kata bank bukan merupakan kata yang asing dan aneh. Menyebut kata bank setiap orang selalu mengaitkannya dengan uang. Sehingga selalu saja ada anggapan bahwa yang berhubungan dengan bank selalu $\backslash$ ada kaitannya dengan uang. Hal ini tidak salah, karena bank merupakan lembaga keuangan atau perusahaan yang bergerak di bidang keuangan. Sebagai lembaga keuangan, bank menyediakan berbagai jasa keuangan.

Dalam dunia modern saat ini, perananan perbankan dalam memajukan negara sangatlah besar. Hampir semua sektor yang berkaitan dengan kegiatan keuangan selalu membutuhkan jasa bank. Oleh karena saat ini dan di masa yang akan datang, kita tidak akan lepas dari dunia perbankan, jika hendak menjalankan aktivitas keuangan, baik perorangan maupun lembaga, baik sosial atau perusahaan.

Pengertian bank yang dikutip berikut ini, pada dasarnya berbeda satu dengan yang lainnya. Kalaupun ada perbedaan hanya nampak pada tugas atau usaha bank. Ada yang mengartikan bank sebagai suatu badan yang tugas utamanya menghimpun dana dari pihak ketiga kemudian menyalurkannya dalam bentuk kredit dalam rangka meningkatkan taraf hidup orang banyak. Sedangkan pengertian lain mengatakan, bank adalah suatu badan yang tugas utamanya sebagai perantara untuk menyalurkan penawaran dan permintaan kredit pada waktu yang ditentukan.

Dendy Wijaya (2014: 25), mendefinisikan bahwa "Bank adalah suatu badan usaha yang tugas utamanya sebagai lembaga perantara keuangan (financial intermediaries), yang menyalurkan dana dari pihak yang berkelebihan dana (idle fund/surplus unit) kepada pihak yang membutuhkan dana atau kekurangan dana (deficit unit) pada waktu yang ditentukan".

Sedangkan menurut Mohammad Najib (2015: 54), "Bank adalah suatu badan usaha yang menghimpun dana dari masyarakat dalam bentuk simpanan dan menyalurkannya ke masyarakat dalam bentuk kredit dan atau bentuk-bentukbentuk lainnya dalam rangka meningkatkan taraf hidup orang banyak".

\section{Pengertian Laporan Keuangan}

Laporan keuangan pada dasarnya disusun untuk memberitahukan informasi mengenai keadaan suatu perusahaan yang akan bermanfaat bagi sebagian besar pemakai laporan keuangan tersebut. Laporan keuangan disusun dan disajikan selama setahun disajikan untuk memenuhi kebutuhan pihak internal perusahaan maupun pihak ekstern perusahaan. Pihakpihak yang berkepentingan terhadap perkembangan suatu perusahaan sangat berbeda dan berhak untuk memperoleh informasi keuangan. Laporan keuangan dipergunakan oleh manajemen puncak untuk dapat mengambil keputusan yang bermanfaat bagi perkembangan perusahaan sedangkan bagi investor laporan keuangan juga berguna dalam pengambilan keputusan, apakah ingin menanamkan saham atau tidak dalam perusahaan tersebut.

Pengertian laporan keuangan dalam Standar Akuntansi Keuangan menurut Ikatan Akuntan Indonesia (2015: 1), 
"Laporan keuangan adalah suatu penyajian terstruktur dari posisi keuangan dan kinerja keuangan suatu entitas".

Kasmir (2016: 7), menyatakan "Laporan keuangan adalah laporan yang menunjukkan kondisi keuangan perusahaan pada saat ini atau dalam suatu priode tertentu.

Kemudian menurut Munawir (2012: 2), "Laporan keuangan pada dasarnya adalah hasil dari proses akuntansi yang dapat digunakan sebagai alat untuk berkomunikasi antara data keuangan atau aktivitas suatu perusahaan dengan pihakpihak yang berkepentingan dengan data atau aktivitas suatu perusahaan.

\section{Rasio Keuangan Bank}

Pada penelitian ini agar dapat memperoleh gambaran tentang perkembangan keuangan suatu perusahaan perlu dilakukan interprestasi atau analisa terhadap data keuangan dari PT Bank UOB Tbk dan data keuangan tersebut tercermin dalam laporan keuangan. Dalam mengadakan interprestasi dan analisa laporan keuangan suatu perusahaan, maka diperlukan adanya ukuran tertentu. Ukuran yang sering digunakan dalam analisa keuangan adalah rasio keuangan.

Dalam penelitian ini menganalisis laporan keuangan PT UOB Indonesia Tbk dengan rasio CAMEL dengan aspek-aspek sebagai berikut :

1. Capital (Modal)

Rasio yang digunakan dalam perhitungan ini adalah Capital Adequency Ratio (CAR), yaitu merupakan perbandingan jumlah modal dengan jumlah aktiva tertimbang menurur ratio (ATMR).

2. Assets Quality (Kualitas aset)
Penilaian didasarkan kepada kualitas aktiva yang dimiliki Bank. Rasio yang diukur ada 2 macam yaitu :

a. Rasio aktiva produktif yang diklasifikasikan terhadap aktiva produktif.

b. Rasio penyisihan penghapusan aktiva produktif terhadap aktiva produktif yang diklasifikasikan.

3. Management (Manajemen)

Penilaian didasarkan kepada manajemen permodalan, manajemen aktiva, manajemen rentabilitas, manajemen likuiditas dan manajemen umum. Manajemen bank dinilai atas dasar 250 pertanyaan yang diajukan.

4. Earning (Rentabilitas)

Penilaian didasarkan kepada rentabilitas suatu bank yaitu melihat kemampuan suatu bank dalam menciptakan laba. Penilaian dalam unsur ini didasarkan kepada 2 macam yaitu :

a. Rasio Laba terhadap total asset (Return Of Assets).

b. Rasio beban operasional terhadap pendapatan operasional (BOPO).

5. Liquidity (Likiuditas)

Yaitu untuk menilai likuiditas bank. Penilaian likuiditas bank didasarkan kepada 2 macam rasio yaitu :

a. Rasio jumlah kewajiban bersih Call Money terhadap aktiva lancar dan yang termasuk aktiva lancar adalah Kas, Giro pada BI, Sertifikat Bank Indonesia (SBI) dan Surat Berharga Pasar Uang (SBPU) yang sudah diendos oleh bank lain.

b. Rasio antara kredit terhadap dana yang diterima oleh Bank (LDR)

\section{METODE PENELITIAN}


47 | Sri Novita. Analisis Kinerja Keuangan Pt Bank Uob Indonesia, Tbk Dengan Metode Camel (Capital, Asset, Management, Earning, Liquidity) Periode 2016 S.D 2018

Penelitian ini menggambarkan objek yang diteliti berdasarkan fakta dan data-data yang ada sebagaimana adanya pada saat penelitian dengan objek PT Bank UOB Indonesia Tbk. Metode deskriptif ialah suatu metode dalam meneliti status sekelompok manusia, suatu proyek, suatu set kondisi, suatu sistem pikiran, atau pun suatu kelas peristiwa pada masa sekarang. Tujuan dari penelitian deskritif ini adalah untuk membuat deskripsi, gambaran, atau lukisan secara sistematis, faktual dan akurat mengenai fakta-fakta, sifat-sifat serta hubungan antara fenomena yang diselidiki. Alat-alat pengumpulan data berupa buku catatan, yang dimaksud dengan buku catatan yaitu berupa catatancatatan atau dokumen-dokumen tentang hasil laporan neraca dan laporan laba rugi dari tahun 2016-2018 pada PT Bank UOB Indonesia Tbk.

Model metode analisis data yang digunakan adalah model analisis deskriptif.

1. Capital (Permodalan)

Rasio yang digunakan dalam perhitungan ini adalah Capital Adequacy Ratio (CAR), yaitu merupakan perbandingan jumlah modal dengan jumlah Aktiva Tertimbang Menurut Risiko (ATMR).

$$
\mathrm{CAR}=\frac{\text { Modal }}{\text { Aktiva Tertimbang Menurut resiko }} \times 100 \%
$$

a. Nilai Kredit Rasio CAR = $\frac{\text { Rasio }}{0,1}+1$

b. NK Faktor CAR = NK Rasio CAR x Bobot Rasio CAR

2. Assets (Kualitas Aktiva Produksi)
2. Perhitungan kualitas aktiva produktif (KAP) menggunakan 2 rasio, Yaitu rasio aktiva produktif yang diklasifikasikan terhadap jumlah aktiva produktif dan rasio penyisihan aktiva produktif yang wajib dibentuk.

a. Rasio aktiva produktif yang diklasifikasikan terhadap jumlah aktiva produktif, yaitu:

Rasio KAP $=\frac{\text { Aktiva Produktif yang Diklasifikasikan }}{\text { Total Aktiva Produktif }} \times 100 \%$

Nilai Kredit RASIO KAP $=\frac{22,5 \%-\text { Rasio KAP }}{0,15 \%}$

Perhitungan NK Faktor KAP $=$ NK

KAP X Bobot KAP

penyisihan penghapus aktiva produktif yang wajib dibentuk

b. Rasio penyisihan penghapus (PPAPWD), yaitu :

aktiva produktif (PPAP) terhadap

$$
\begin{aligned}
& \text { Rasio PPAP }=\frac{\text { PPAP }}{\text { PPAPWD }} \times 100 \% \\
& \text { Nilai Kredit PPAP }=\frac{\text { Rasio PPAP }}{1 \%}
\end{aligned}
$$

NK Faktor PPAP = NK Rasio PPAP x Bobot PPAP 
3. Earning (Rentabilitas

Aspek Earning (Rentabilitas), yaitu untuk menggambarkan kemampuan perusahaan untuk mendapatkan laba melalui semua kemampuan dan sumber yang ada, seperti kegiatan penjualan,

$$
\mathrm{ROA}=\frac{\text { Laba sebelum Pajak }}{\text { Julmlah aktiva }} \times 100 \%
$$

Kemudian mencari nilai kreditnya, dengan formulasi sebagai berikut:

$$
\begin{gathered}
\text { Nilai Kredit Rasio ROA }=\frac{\text { Rasio ROA }}{0,015 \%} \\
\text { NK Faktor ROA }=\text { NK Rasio ROA x Bobot Rasio ROA }
\end{gathered}
$$

b. Rasio Biaya Operasional terhadap Pendapatan Operasional (BOPO).

$$
\mathrm{BOPO}=\frac{\text { Biaya Operasional }}{\text { Pendapatan Operasioanal }} \times 100 \%
$$

NK Faktor BOPO = NK BOPO $x$ Bobot Rasio BOPO

\section{Liquiditas (Likuiditas)}

Perhitungan likuiditas mengunakan 2 rasio, yaitu :

$$
\mathrm{NCM}-\mathrm{CA}=\frac{\text { Kewajiban Bersih Call Money }}{\text { Aktiva Lancar }} \times 100 \%
$$

Kemudian mencari nilai kreditnya, dengan formulasi sebagai berikut:

$$
\mathrm{NK} N C M-\mathrm{CA}=\frac{100 \%-\text { Rasio NCM }-\mathrm{CA}}{1 \%}
$$

NK Faktor NCM-CA = NK NCM-CA $x$ Bobot NCM-CA

b. Rasio Kredit yang Diberikan terhadap Dana yang Diterima (Loan to Deposito Ratio / LDR)

$$
\mathrm{LDR}=\frac{\text { Kredit yang diberikan }}{\text { Dana yang diterima }} \times 100 \%
$$

Kemudian mencari nilai kreditnya, dengan formulasi sebagai berikut:

$$
\text { NK LDR }=\frac{115 \%-\text { Rasio LDR }}{1 \%}
$$

NK Faktor LDR = NK Rasio LDR x Bobot Rasio LDR 


\section{HASIL DAN PEMBAHASAN}

\section{Tabel 1}

Nilai Bersih Rasio CAMEL tahun 2016

PT Bank UOB Indonesia Tbk

\begin{tabular}{|c|c|c|c|c|}
\hline Nama Rasio & Angka Rasio & $\begin{array}{c}\text { Nilai Kotor } \\
\text { Rasio }\end{array}$ & Bobot \% & $\begin{array}{c}\text { Nilai Bersih } \\
\text { Rasio }\end{array}$ \\
\hline \multicolumn{5}{|c|}{ Capital/Permodalan } \\
\hline CAR & $14,24 \%$ & 100 & 25 & 25 \\
\hline \multicolumn{5}{|c|}{ Asset/Aktiva Produktif } \\
\hline KAP & $5,16 \%$ & 100 & 25 & 25 \\
\hline PPAP & $59,44 \%$ & 100 & 5 & 2,95 \\
\hline \multicolumn{5}{|c|}{ Management/Manajemen } \\
\hline Manajemen & 100 & 100 & 25 & 25 \\
\hline \multicolumn{5}{|c|}{ Earning/Rentabilitas } \\
\hline $\mathrm{ROA}$ & $7,11 \%$ & 100 & 5 & 5 \\
\hline BOPO & $34,24 \%$ & 100 & 5 & 5 \\
\hline CR & $11,29 \%$ & 100 & 5 & 5 \\
\hline LDR & $62,83 \%$ & 52,17 & 5 & 2,6 \\
\hline \multicolumn{4}{|c|}{ Jumlah Nilai Bersih Rasio CAMEL 2016} & 95,55 \\
\hline
\end{tabular}

Sumber: Data Olahan, 2020

Dari tabel 1 di atas, Rasio CAR menunjukkan kemampuan PT Bank UOB Indonesia Tbk untuk menutupi penurunan aktivanya sebagai akibat dari kerugiankerugian bank yang disebabkan oleh aktiva yang beresiko sebesar 14,24\%. Pada angka Rasio KAP dapat menunjukkan aktiva produktif yang bermasalah pada PT Bank UOB Indonesia Tbk sebesar 5,16\%. Pada angka Rasio PPAP dapat menunjukkan kemampuan PT Bank UOB Indonesia Tbk dalam mengantisipasi penghapusan kredit macet sebesar 59,44\%. Pada angka Manajemen menunjukkan kemampuan PT Bank UOB Indonesia Tbk dalam menjalankan operasionalnya secara efisien baik untuk waktu sekarang ataupun diwaktu yang akan datang sebesar 100\%. Pada angka Rasio ROA dapat menunjukkan kemampuan PT Bank UOB Indonesia Tbk didalam memperoleh laba dan efisiensi secara keseluruhan sebesar 7,11\%. Pada angka Rasio 
BOPO dapat menunjukkan tingkat efisiensi dan kemampuan PT Bank UOB Indonesia Tbk dalam melakukan kegiatan operasionalnya sebesar $34,24 \%$. Pada angka Rasio CR dapat menunjukkan kemampuan aktiva lancar PT Bank UOB indonesia Tbk dalam memenuhi kewajiban lancar yang segera jatuh tempo sebesar 11,29\%. Pada angka Rasio LDR menunjukkan kemampuan PT Bank UOB Indonesia Tbk didalam membayar kembali penarikan dana yang dilakukan oleh deposan dengan mengandalkan kredit yang diberikan sebagai sumber likuiditasnya sebesar 62,83\%. Rasio CAMEL tahun 2016 diperoleh nilai sebesar 95,55\%, ini menunjukkan predikat kesehatan PT Bank UOB Indonesia Tbk sesuai dengan standar yang telah ditetapkan oleh Bank Indonesia dan dikategorikan Sehat.

Tabel 2

Nilai Bersih Rasio CAMEL tahun 2017

PT Bank UOB Indonesia Tbk

\begin{tabular}{|c|c|c|c|c|}
\hline Nama Rasio & $\begin{array}{c}\text { Angka } \\
\text { Rasio }\end{array}$ & $\begin{array}{c}\text { Nilai Kotor } \\
\text { Rasio }\end{array}$ & Bobot \% & $\begin{array}{c}\text { Nilai Bersih } \\
\text { Rasio }\end{array}$ \\
\hline \multicolumn{5}{|c|}{ Capital/Permodalan } \\
\hline CAR & $14,41 \%$ & 100 & 25 & 25 \\
\hline \multicolumn{5}{|c|}{ Asset/Aktiva Produktif } \\
\hline KAP & $3,59 \%$ & 100 & 25 & 25 \\
\hline PPAP & $67,36 \%$ & 67,36 & 5 & 3,35 \\
\hline Manajemen & 100 & 100 & 25 & 25 \\
\hline \multicolumn{5}{|c|}{ Earning/Rentabilitas } \\
\hline ROA & $3,23 \%$ & 100 & 5 & 5 \\
\hline BOPO & $34,58 \%$ & 100 & 5 & 5 \\
\hline \multicolumn{5}{|c|}{ Liquidity/Likuiditas } \\
\hline CR & $11,29 \%$ & 100 & 5 & 5 \\
\hline LDR & $3,22 \%$ & 52,17 & 5 & 98,35 \\
\hline
\end{tabular}

Sumber: Data Olahan, 2020

Dari tabel 2 di atas, angka

rasio CAR menunjukkan kemampuan PT Bank UOB Indonesia Tbk untuk menutupi penurunan aktivanya sebagai akibat dari kerugian-kerugian bank yang disebabkan oleh aktiva yang beresiko sebesar $14,41 \%$. 
Pada angka Rasio KAP dapat menunjukkan aktiva produktif yang bermasalah pada PT Bank UOB Indonesia Tbk sebesar 3,59\%. Pada angka Rasio PPAP dapat menunjukkan kemampuan PT Bank UOB Indonesia Tbk dalam mengantisipasi penghapusan kredit macet sebesar 67,36\%. Pada angka Manajemen menunjukkan kemampuan PT Bank UOB Indonesia Tbk dalam menjalankan operasionalnya secara efisien baik untuk waktu sekarang ataupun diwaktu yang akan datang sebesar $100 \%$. Pada angka Rasio ROA dapat menunjukkan kemampuan PT Bank UOB Indonesia Tbk didalam memperoleh laba dan efisiensi secara keseluruhan sebesar 3,23\%. Pada angka Rasio BOPO dapat menunjukkan tingkat efisiensi dan kemampuan PT Bank UOB Indonesia Tbk dalam melakukan kegiatan operasionalnya sebesar $34,58 \%$. Pada angka Rasio CR dapat menunjukkan kemampuan aktiva lancar PT Bank UOB indonesia
Tbk dalam memenuhi kewajiban lancar yang segera jatuh tempo sebesar 11,29\%. Pada angka Rasio LDR menunjukkan kemampuan PT Bank UOB Indonesia Tbk didalam membayar kembali penarikan dana yang dilakukan oleh deposan dengan mengandalkan kredit yang diberikan sebagai sumber likuiditasnya sebesar $3,22 \%$.

Pada Nilai kotor rasio dan bobot yang diberikan sudah menggunakan standar yang telah ditetapkan oleh Bank Inddonesia. Sedangkan pada Nilai rasio bersih merupakan hasil dari perkalian nilai rasio dengan bobot kemudian akan dijumlahkan dari seluruh rasio CAMEL dan diperoleh Nilai bersih rasio CAMEL. Kemudian pada nilai Rasio CAMEL tahun 2017 diperoleh nilai sebesar $98,35 \%$, ini menunjukkan predikat kesehatan PT Bank UOB Indonesia Tbk sesuai dengan standar yang telah ditetapkan oleh Bank Indonesia dan dikategorikan Sehat.

Tabel 3

Nilai Bersih Rasio CAMEL tahun 2018

PT Bank UOB Indonesia Tbk

\begin{tabular}{|c|c|c|c|c|}
\hline Nama Rasio & $\begin{array}{c}\text { Angka } \\
\text { Rasio }\end{array}$ & $\begin{array}{c}\text { Nilai Kotor } \\
\text { Rasio }\end{array}$ & Bobot \% & $\begin{array}{c}\text { Nilai Bersih } \\
\text { Rasio }\end{array}$ \\
\hline \multicolumn{5}{|c|}{ Capital/Permodalan } \\
\hline CAR & $13,22 \%$ & 100 & 25 & 25 \\
\hline \multicolumn{5}{|c|}{ Asset/Aktiva Produktif } \\
\hline KAP & $2,69 \%$ & 100 & 25 & 25 \\
\hline PPAP & $67,36 \%$ & 42,49 & 5 & 2,1 \\
\hline
\end{tabular}




\begin{tabular}{|c|c|c|c|c|}
\hline \multicolumn{5}{|c|}{ Management/Manajemen } \\
\hline Manajemen & 100 & 100 & 25 & 25 \\
\hline \multicolumn{5}{|c|}{ Earning/Rentabilitas } \\
\hline ROA & $6,85 \%$ & 100 & 5 & 5 \\
\hline BOPO & $35,11 \%$ & 100 & 5 & 5 \\
\hline \multicolumn{5}{|c|}{ Liquidity/Likuiditas } \\
\hline CR & $11,23 \%$ & 100 & 5 & 5 \\
\hline LDR & $18,88 \%$ & 96,12 & 5 & 4,8 \\
\hline \multicolumn{6}{|c|}{ Jumlah Nilai Bersih Rasio CAMEL 2018 } & $\mathbf{9 6 , 9}$ \\
\hline
\end{tabular}

Sumber: Data Olahan, 2020

Dilihat dari tabel 3 di atas, angka Rasio CAR dapat menunjukkan kemampuan PT Bank UOB Indonesia Tbk untuk menutupi penurunan aktivanya sebagai akibat dari kerugiankerugian bank yang disebabkan oleh aktiva yang beresiko sebesar 13,22\%. Pada angka Rasio KAP dapat menunjukkan aktiva produktif yang bermasalah pada PT Bank UOB Indonesia Tbk sebesar 2,69\%. Pada angka Rasio PPAP dapat menunjukkan kemampuan PT Bank UOB Indonesia Tbk dalam mengantisipasi penghapusan kredit macet sebesar 42,49\%. Pada angka Manajemen menunjukkan kemampuan PT Bank UOB Indonesia Tbk dalam menjalankan operasionalnya secara efisien baik untuk waktu sekarang ataupun diwaktu yang akan datang sebesar $100 \%$. Pada angka Rasio ROA dapat menunjukkan kemampuan PT Bank UOB Indonesia Tbk didalam memperoleh laba dan efisiensi secara keseluruhan sebesar 6,85\%. Pada angka Rasio BOPO dapat menunjukkan tingkat efisiensi dan kemampuan PT Bank UOB Indonesia Tbk dalam melakukan kegiatan operasionalnya sebesar $35,11 \%$. Pada angka Rasio CR dapat menunjukkan kemampuan aktiva lancar PT Bank UOB indonesia Tbk dalam memenuhi kewajiban lancar yang segera jatuh tempo sebesar 11,23\%. Pada angka Rasio LDR menunjukkan kemampuan PT Bank UOB Indonesia Tbk didalam membayar kembali penarikan dana yang dilakukan oleh deposan dengan mengandalkan kredit yang diberikan sebagai sumber likuiditasnya sebesar $18,88 \%$.

Pada Nilai kotor rasio dan bobot yang diberikan sudah menggunakan standar yang telah ditetapkan oleh Bank Indonesia. Sedangkan pada Nilai rasio bersih merupakan hasil dari perkalian nilai rasio dengan bobot kemudian akan dijumlahkan dari seluruh rasio CAMEL dan diperoleh Nilai bersih rasio CAMEL. Kemudian pada nilai Rasio CAMEL tahun 2018 diperoleh nilai sebesar $96,9 \%$ ini 
menunjukkan predikat kesehatan PT Bank UOB Indonesia Tbk sesuai dengan standar yang telah ditetapkan oleh Bank Indonesia dan dikategorikan Sehat.

Tabel 4

Predikat Tingkat Kesehatan Bank

\begin{tabular}{|c|c|}
\hline Nilai Kredit & Predikat \\
\hline $81-100$ & Sehat \\
\hline $66-<81$ & Cukup Sehat \\
\hline $51-<66$ & Kurang Sehat \\
\hline $0-<51$ & Tidak Sehat \\
\hline
\end{tabular}

Sumber: Surat Edaran Bank Indonesia Nomor: 6/23/DPNP tanggal 31 Mei 2004

Tabel 5

Hasil Perhitungan Rasio CAMEL PT Bank UOB Indonesia Tbk

\begin{tabular}{|c|c|c|}
\hline Tahun & Nilai CAMEL & Predikat \\
\hline 2016 & 95,55 & Sehat \\
\hline 2017 & 98,35 & Sehat \\
\hline 2018 & 96,9 & Sehat \\
\hline
\end{tabular}

Sumber: Data Olahan, 2020

Berdasarkan

hasil

perhitungan, dapat disimpulkan bahwa masing-masing rasio yang tertera pada tabel di atas menunjukkan nilai bersih aspek (CAMEL) pada tahun 2016 sebesar 95,55 poin, pada tahun

\section{KESIMPULAN}

Dari hasil penelitian yang telah dilakukan, yang menjadi keimpulan dalam penelitian ini adalah:

a) CAR PT Bank UOB Indonesia Tbk per 31 Desember 2016 sebesar $14,29 \%$, tahun 2017 sebesar $14,41 \%$, dan tahun 2018 sebesar $13,22 \%$. Hal ini menunjukkan dari tahun 2016 hingga 2017 rasio CAR PT Bank UOB Indonesia Tbk mengalami peningkatan,
2017 sebesar 98,35 poin dan pada tahun 2018 sebesar 96,9 poin. Artinya tingkat kesehatan PT Bank UOB Indonesia Tbk sesuai dengan standar yang telah ditetapkan oleh Bank Indonesia dan dikategorikan Sehat. sedangkan tahun 2018 mengalami penurunan nilai rasio sebesar $1 \%$ dari tahun sebelumnya. Hal ini terjadi karena kenaikan jumlah modal dan kenaikan jumlah ATMR.

b) KAP PT Bank UOB Indonesia Tbk per 31 Desember 2016 sebesar $5,16 \%$, tahun 2017 sebesar 3,59\%, dan tahun 2018 sebesar 2,69\%. Dari hasil tersebut terlihat bahwa rasio KAP mengalami penurunan 
pada setiap tahunnya. Hal ini desebabkan karena Aktiva Produktif yang Diklasifikasikan mengalami penurunan.

c) ROA PT Bank UOB Indonesia Tbk per 31 Desember 2016 sebesar $7,11 \%$, tahun 2017 sebesar 3,23\%, dan pada tahun 2018 sebesar $6,85 \%$. Hal ini menunjukkan dari tahun 2016 hingga tahun 2018 rasio ROA PT Bank UOB Indonesia Tbk mengalami penurunan. Ketidak tetapan nilai rasio ROA ini menunjukkan bahwa kurang baiknya pengelolaan asset PT Bank UOB Indonesia Tbk dalam menghasilkan laba.

d) BOPO PT Bank UOB Indonesia Tbk per 31 Desember 2016 sebesar $34,24 \%$, tahun 2017 sebesar $34,58 \%$, dan pada tahun 2018 sebesar 35,11\%. Hal ini menunjukkan dari tahun 2016 hingga tahun 2018 rasio BOPO PT Bank UOB Indonesia Tbk mengalami kenaikan setiap tahunnya. adapun semakin menurun rasio ini berarti PT Bank UOB Indonesia Tbk semakin efisien dalam melakukan kegiatan operasionalnnya.

\section{REFERENSI}

Dendy Wijaya,dkk. 2014. Analisis Wacana Pragmatik Kajian Teori dan Analisis. Surakarta: Yuma Pustaka. Harmono. 2011. Manajemen Keuangan Berbasis Balanced. Jakarta: PT Bumi Angkasa Raya

Ikatan Akuntansi Indonesia. 2015. Pernyataan Standar Akuntansi Keuangan. Jakarta: Ikatan Akuntansi Indonesia. e) CR PT Bank UOB Indonesia Tbk per 31 Desember 2016 sebesar 11,29\%, tahun 2017 sebesar $11,29 \%$, dan pada tahun 2018 sebesar 11,23\%. Hal ini menunjukkan dari tahun 2016 hingga tahun 2018 rasio CR PT Bank UOB Indonesia Tbk mengalami penurunan nilai pada tahun 2018. Penurunan nilai rasio ini dikarenakan adanya peningkatan nilai utang lancar diiringi peningkatan aktiva lancar tetapi tingkat keuntungan terhadap beban lebih kecil dari tahun sebelumnya yang dimiliki oleh PT Bank UOB Indonesia Tbk.

f) LDR PT Bank UOB Indonesia Tbk per 31 Desember 2016 sebesar $62,83 \%$, tahun 2017 sebesar $3,22 \%$, dan pada tahun 2018 sebesar 18,88\%. Hal ini menunjukkan dari tahun 2016 hingga tahun 2018 rasio BOPO PT Bank UOB Indonesia Tbk mengalami fluktuasi setiap tahunnya. Semakin tinggi nilai rasio ini memberikan indikasi semakin rendahnya kemampuan likuiditas PT Bank UOB Indonesia Tbk tersebut.
Kasmir. 2016. Analisa Laporan Keuangan Cetakan Ke-10. Jakarta: PT Raja Grafindo Persada.

Mohammad Najib, dkk. 2015. Manajemen Keuangan Modern. Jakarta: PT Raja Grafindo Persada

Munawir. 2012. Analisia Laporan Keuangan. Yogyakarta: Liberty

Peraturan Bank Indonesia Nomor 6/10/PBI/2004 tanggal 12 April 
55 | Sri Novita. Analisis Kinerja Keuangan Pt Bank Uob Indonesia, Tbk Dengan Metode Camel (Capital, Asset, Management, Earning, Liquidity) Periode 2016 S.D 2018

2004 tentang Sistem Penilaian Tingkat Kesehatan Bank Umum (Lembaran Negara Republik

Indonesia Tahun 2004 Nomor 38, Tambahan Lembaran Negara Nomor 4382)

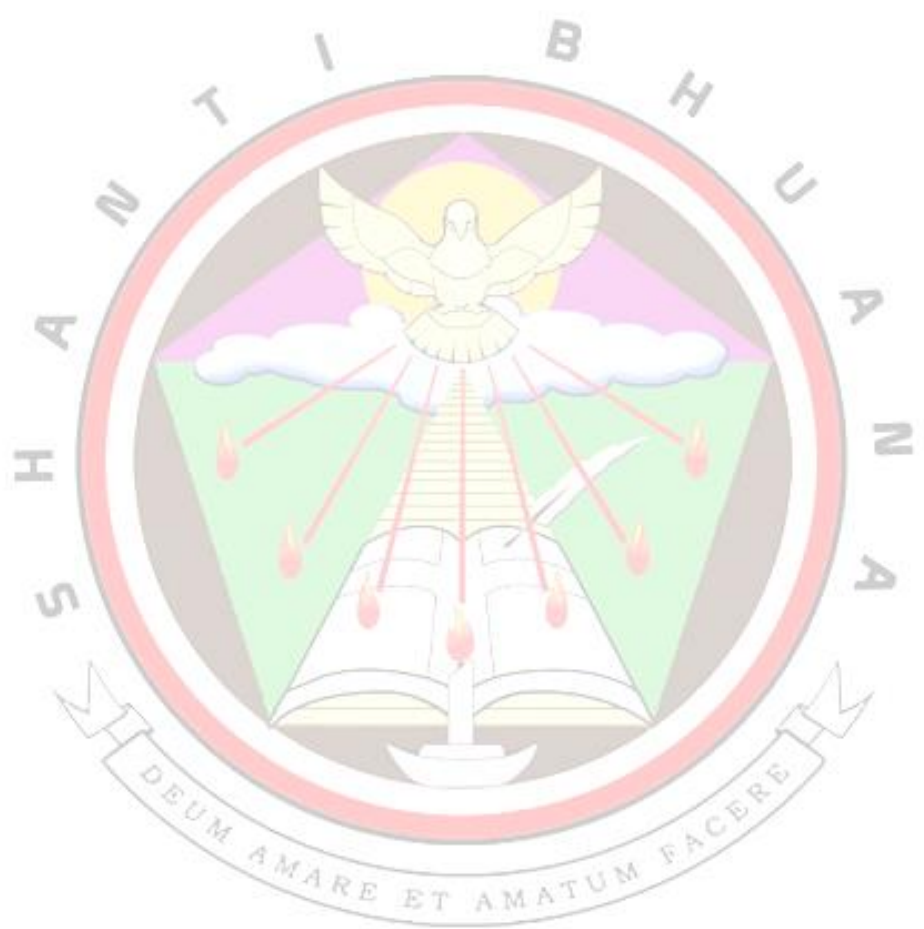

